Jurnal Keperawatan Silampari

Volume 5, Nomor 1, Desember 2021

e-ISSN: 2581-1975

p-ISSN: 2597-7482

DOI: https://doi.org/10.31539/jks.v5i1.2972

IDMEKpE

\title{
PELATIHAN BANTUAN HIDUP DASAR TERHADAP PENGETAHUAN DAN KETERAMPILAN ANGGOTA PMR
}

\author{
Arya Ramadia ${ }^{1}$, Ahmad Redho $^{2}$, Fifi Sri Nofa ${ }^{3}$ \\ Sekolah Tinggi Ilmu Kesehatan Al Insyirah ${ }^{1,2,3}$ \\ ahmadredho49@gmail.com²
}

\begin{abstract}
ABSTRAK
Penelitian ini bertujuan untuk mengetahui pengaruh pemberian pelatihan RJP terhadap tingkat pengetahuan dan keterampilan anggota PMR. Metode penelitian menggunakan desain quasy experiment dengan pendekatan one group pre-post test design. Hasil penelitian menunjukkan bahwa mayoritas umur responden berusia 17 tahun yaitu 12 orang (48\%). Jenis kelamin diketahui bahwa mayoritas jenis kelamin responden adalah perempuan yaitu sebanyak 14 responden $(56 \%)$. Rata-rata nilai pengetahuan responden dalam melakukan tindakan RJP sebelum diberikan pelatihan yaitu rata-rata/mean 7,56 (SD 2.2) dan sesudah pelatihan nilai rata-rata meningkat 13,04 dengan (SD 1,46). Analisis data menggunakan uji paired t test dengan hasil $\mathrm{p}<0,00$ ( $\mathrm{p}$ value $<0,05$ ). Simpulan, terdapat pengaruh pelatihan tindakan RJP terhadap pengetahuan dan keterampilan sebelum dan sesudah diberikan pelatihan. Dengan adanya pelatihan tindakan RJP maka akan dapat meningkatkan pengetahuan dan keterampilan anggota PMR sehingga akan dapat terciptanya bystander yang lebih banyak terutama dikalangan usia muda.
\end{abstract}

Kata Kunci: Bantuan Hidup Dasar, Keterampilan, Pengetahuan

\section{ABSTRACT}

This study aims to determine the effect of providing CPR training on the level of knowledge and skills of PMR members. The research method uses a quasi-experimental design with a one group pre-post test design approach. The results showed that the majority of respondents were 17 years old, namely 12 people (48\%). Gender, it is known that the majority of respondents' gender is female, as many as 14 respondents $(56 \%)$. The average value of respondents' knowledge in performing CPR before being given training was an average of 7.56 (SD 2.2) and after training the average value increased by 13.04 (SD 1.46). Data analysis used paired t test with $p<0.00$ ( $p$ value < 0.05). In conclusion, there is an effect of CPR action training on knowledge and skills before and after being given training. With the CPR action training, it will be able to increase the knowledge and skills of PMR members so that more bystanders can be created, especially among young people.

Keywords: Basic Life Support, Skills, Knowledge 


\section{PENDAHULUAN}

Bantuan Hidup Dasar (BHD) merupakan sekumpulan intervensi yang bertujuan untuk mengembalikan dan mempertahankan fungsi vital organ pada korban henti jantung dan henti nafas. Intervensi ini terdiri dari pemberian kompresi dada dan bantuan nafas yang disebut dengan tindakan Resusitasi Jantung Paru (RJP). RJP adalah suatu tindakan yang dilakukan untuk membantu korban yang mengalami henti jantung, tindakan dapat dilakukan oleh masyarakat awam yang sudah dilatih untuk melakukan tindakan BHD atau RJP (Priosusilo, 2019).

Data World Health Organization (WHO) tahun 2016 yang menyebutkan bahwa 56 juta kematian diseluruh dunia, 38 juta diantaranya disebabkan oleh penyakit tidak menular (PTM) dan proporsi penyebab utama kematian PTM pada tahun 2016 itu diantaranya; penyakit kardiovaskular $(37 \%)$, kanker (27\%), penyakit pernapasan $(8 \%)$ dan diabetes (4\%). Selanjutnya, WHO juga melaporkan bahwa kematian karena penyakit kardiovaskular tersebut 7,4 juta disebabkan oleh penyakit jantung koroner (PJK) dan sebesar 6,7 juta orang disebabkan oleh stroke. Sample Registration System (SRS) Indonesia tahun 2014 menunjukkan PJK merupakan penyebab kematian tertinggi kedua setelah stroke, yaitu sebesar 12,9\% dari seluruh penyebab kematian tertinggi di Indonesia (Amisi et al., 2018).

Pelatihan BHD perlu diberikan kepada masyarakat awam khususnya kelompok remaja mengingat 22.139.400 juta jiwa dari 269,6 juta jiwa pada 2020 merupakan kelompok usia remaja (BPS, 2020). Pelatihan BHD khususnya RJP untuk kalangan siswa menengah atas di Indonesia juga sudah dilaksanakan walaupun belum merata di semua daerah atau propinsi yang ada, seperti SMAN 7 Pontianak pada tanggal 1 Oktober 2017 dan seluruh siswa dan siswi utusan SMA se-Singkawang pada tanggal 31 Oktober 2017 (HIPGABI, 2017).

Berdasarkan wawancara dengan beberapa anggota PMR pada sekolah menengah atas seperti SMAN 1, SMAN 2, SMAN 5 dan SMAN 6 Pekanbaru pelatihan kegawatdaruratan yang didapat baru sebatas pembidaian, stop perdarahan, membatu seseorang pingsan di saat upacara sekolah, namun pelatihan BHD khususnya RJP belum pernah didapat pelatihannya. Oleh karena itu anggota PMR pada tingkat SMA perlu mendapatkan pelatihan BHD khususnya RJP. Berdasarkan survei yang dilakukan pada bulan April 2020 di SMAN 1 Pekanbaru dengan pembimbing PMR didapatkan juga informasi yang sama bahwa siswa terutama anggota PMR belum pernah mendapatkan pelatihan BHD khususnya RJP. Namun pelatihan ini di beri secara online untuk materi dan offline pelatihan.

\section{METODE PENELITIAN}

Jenis metode penelitian yang digunakan adalah metode kuantitatif dengan desain penelitian quasy eksperiment dan pendekatan one group pre-post test design. Penelitian ini mengungkapkan sebab akibat dengan cara melibatkan suatu kelompok subjek. Kelompok subjek diobservasi sebelum dilakukan intervensi, kemudian diobservasi lagi setelah intervensi. Populasi adalah siswa SMAN 1 Pekanbaru dengan sampel 25 responden anggota PMR SMAN 1 Pekanbaru. Pengambilan sampel menggunakan total sampling. Alat pengumpulan data menggunakan kuesioner tentang BHD untuk menilai pengetahuan dan menggunakan SOP RJP untuk keterampilan dan analisa data dilakukan secara univariat dan bivariat. 
HASILPENELITIAN

Analisis Univariat

Kararteristik responden

Tabel. 1

Distribusi Frekuensi Karakteristik Responden

berdasarkan Umur dan Jenis Kelamin $(n=25)$

\begin{tabular}{clcc}
\hline No & \multicolumn{1}{c}{ Karakteristik } & F & $\%$ \\
\hline 1 & Umur & & \\
& 15 & 6 & 24 \\
& 16 & 7 & 28 \\
& 17 & 12 & 48 \\
\hline 2 & Jenis Kelamin & & \\
& Laki-laki & 11 & 44 \\
& Perempuan & 14 & 56 \\
\hline & Total & 25 & 100 \\
\hline
\end{tabular}

Berdasarkan tabel 1 menunjukkan bahwa mayoritas umur responden berusia 17 tahun yaitu 12 orang (48\%). Jenis kelamin diketahui bahwa mayoritas jenis kelamin responden adalah perempuan yaitu sebanyak 14 responden $(56 \%)$.

Tabel. 2

Rata-Rata Pengetahuan Sebelum dan Sesudah

Diberikan Pelatihan Tindakan RJP $(n=25)$

\begin{tabular}{|c|c|c|c|c|c|}
\hline \multirow{2}{*}{ Variabel } & \multirow{2}{*}{ Mean } & \multirow[b]{2}{*}{$\mathrm{SD}$} & \multirow{2}{*}{$\begin{array}{c}\text { Mean } \\
\text { Difference }\end{array}$} & \multicolumn{2}{|c|}{$95 \% \mathrm{CI}$} \\
\hline & & & & Lower & Upper \\
\hline Pengetahuan Sebelum & 7,56 & 2,2 & 540 & 6747 & 10 \\
\hline Pengetahuan Sesudah & 13,04 & 1,46 & $-5,48$ & $-6,142$ & $-4,218$ \\
\hline
\end{tabular}

Berdasarkan tabel 2 menunjukkan bahwa rata-rata nilai pengetahuan responden dalam melakukan tindakan RJP sebelum diberikan pelatihan yaitu rata-rata/mean 7,56 (SD 2.2) dan sesudah pelatihan nilai rata-rata meningkat 13,04 dengan (SD 1,46).

Tabel. 3

Rata-Rata Keterampilan Sebelum dan Sesudah Diberikan Pelatihan Tindakan RJP $(n=25)$

\begin{tabular}{cccccc}
\hline \multirow{2}{*}{ Variabel } & \multirow{2}{*}{ Mean } & SD & \multirow{2}{*}{$\begin{array}{c}\text { Mean } \\
\text { Difference }\end{array}$} & Lower & Upper \\
\hline Keterampilan Sebelum & 12,60 & 0,82 & & & 95\% CI \\
Keterampilan Sesudah & 28,60 & 1,29 & $-16,00$ & $-16,715$ & $-15,285$ \\
\hline
\end{tabular}

Berdasarkan tabel 3 bahwa rata-rata nilai keterampilan rata-rata/mean sebelum diberikan pelatihan sebesar 12,60 (SD 0,82) dan rata-rata/mean keterampilan sesudah diberikan pelatihan 28,60 (SD 1,29). 


\section{Analisis Bivariat}

Tabel. 4

Distribusi Rata-Rata Responden Berdasarkan Pengetahuan dan Keterampilan Sebelum dan Sesudah Pelatihan Tindakan RJP $(n=25)$

\begin{tabular}{|c|c|c|c|c|c|c|}
\hline \multirow{2}{*}{ Variabel } & \multirow{2}{*}{ Mean } & \multirow{2}{*}{$\mathrm{SD}$} & \multirow{2}{*}{$\begin{array}{c}\text { Mean } \\
\text { Difference }\end{array}$} & \multicolumn{2}{|c|}{$95 \% \mathrm{CI}$} & \multirow{2}{*}{$P$ value } \\
\hline & & & & Lower & Upper & \\
\hline Pengetahuan Sebelum & 7,56 & 2,2 & 548 & 6742 & 1218 & $0 \Omega 0 \Omega$ \\
\hline Pengetahuan Sesudah & 13,04 & 1,46 & $-5,40$ & $-0,142$ & $-4,210$ & 000 \\
\hline Keterampilan Sebelum & 12,60 & 0,82 & $16 \Omega 0$ & 16 & - & ( \\
\hline Keterampilan Sesudah & 28,60 & 1,29 & $-10,00$ & $-10, / 15$ & 15,285 & 0,000 \\
\hline
\end{tabular}

Berdasarkan tabel menunjukkan bahwa rata-rata pengetahuan responden sebelum mendapatkan pelatihan adalah 7,56 (SD 2,2) dan sesudah diberikan pelatihan pengetahuan RJP sebesar 13,04 (SD 1,46). Hasil analisa bivariat menunjukkan $p$-value $0,000(\mathrm{p}<0,05)$ yang artinya terdapat pengaruh yang signifikan sebelum dan sesudah pelatihan. Uji statistic juga menunjukan keterampilan rata-rata sebelum diberikan pelatihan sebesar 12,60 (SD 0,82) dan rata-rata keterampilan sesudah diberikan pelatihan 28,60 (SD 1,29). Hasil analisa bivariat diperoleh p-value $0,000(\mathrm{p}<0,05)$ artinya terdapat pengaruh pelatihan tindakan RJP terhadap keterampilan sebelum dan sesudah diberikan pelatihan.

\section{PEMBAHASAN}

\section{Pengetahuan Sebelum dan Sesudah Diberikan Pelatihan Tindakan RJP}

Hasil penelitian menunjukan bahwa nilai rata-rata pengetahuan responden sebelum pelatihan sebesar 7,56 (SD 2,2) dalam arti pengetahuan responden sebelum pelatihan mayoritas kategori kurang dengan nilai rata-rata $<8$ dan sesudah diberikan pelatihan pengetahuan tindakan RJP meningkat sebesar 13,04 dengan (SD 1,46) dalam arti setelah diberikan pelatihan, pengetahuan responden mayoritas kategori baik dengan rata-rata 12-15. Hasil analisa bivariat menunjukkan $p$ value $0,000(\mathrm{p}<0,05)$ yang artinya terdapat pengaruh yang signifikan sebelum dan sesudah diberikan pelatihan tindakan RJP. Hal ini sama dengan penelitian yang dilakukan Herlina (2019) yang menunjukkan bahwa terdapat pengaruh yang signifikan antara simulasi dengan motivasi dan skill resusitasi dengan $\mathrm{p}$ value $(\mathrm{p}<00,5)$

Hasil penelitian yang dilakukan oleh Achmad \& Partorejo (2020) juga memiliki hasil yang mendukung, bahwa pertolongan pertama yang harus dilakukan oleh responden atau saksi pertama merupakan bagian penting dalam rantai kelangsungan hidup di luar rumah sakit yang dapat meningkatkan prognosis dan menghindari gejala lainnya. Oleh karena itu, penting bagi masyarakat awam untuk mengetahui dan memiliki keterampilan, khususnya resusitasi jantung paru, untuk menangani keadaan darurat tersebut. Sekolah menjadi tempat yang tepat untuk menyelenggarakan pelatihan P3K karena siswa lebih terkondisikan secara emosional, sosial dan budaya. Hasil pretest dan post-test menunjukkan bahwa ada peningkatan pengetahuan setelah pelatihan dengan menggunakan metode ceramah. $(\mathrm{p}=0,000)$, poster $(\mathrm{p}=0,000)$ dan metode audio visual $(\mathrm{p}=0,000)$. Keterampilan resusitasi jantung paru pada kelompok perkuliahan $(\mathrm{p}=0,000)$, poster $(\mathrm{p}=0,000)$ dan metode audio-visual $(\mathrm{p}=0,000)$ menunjukkan peningkatan setelah pelatihan pertolongan pertama di sekolah. Kesimpulan penelitian ini membuktikan bahwa yang pertama pelatihan bantuan di 
sekolah berdampak pada peningkatan pengetahuan dan keterampilan dalam menangani situasi darurat, khususnya henti jantung melalui resusitasi kardiopulmoner.

Dari hal tersebut peneliti dapat menyimpulkan bahwa dalam meningkatkan pengetahuan seseorang harus selalu belajar dan terus belajar baik secara formal maupun non formal seperti mengikuti suatu pelatihan akan dapat menambah pengetahuan seseorang dan dengan meningkatnya pengetahuan sebelum dan sesudah diberikan pelatihan tentang teori pengetahuan dapat merubah responden dalam hal meningkatkan pengetahuan terkait tindakan RJP.

\section{Rata-Rata Keterampilan Sebelum dan Sesudah Diberikan Pelatihan Tindakan RJP}

Hasil penelitian setelah di lakukan uji statistic juga menunjukan keterampilan rata-rata sebelum diberikan pelatihan sebesar 12,60 (SD 0,82), dengan arti tingkat keterampilan responden sebelum diberikan pelatihan mayoritas tidak kompeten karena nilai rata-rata $<26$ dan rata-rata keterampilan sesudah diberikan pelatihan meningkat menjadi 28,60 (SD 1,29), dengan arti keterampilan responden setelah diberikan pelatihan mayoritas kompeten dengan nilai rata-rata 26-32. Hasil analisa bivariat diperoleh $p$ value $0,000(\mathrm{p}<0,05)$ artinya terdapat pengaruh pelatihan tindakan RJP terhadap keterampilan sebelum dan sesudah diberikan pelatihan.

Hasil penelitian ini juga sejalan dengan penelitian yang dilakukan oleh Prasetyo (2018) menunjukan bahwa nilai rata-rata keterampilan responden sebelum pelatihan sebesar 2,83 $\pm 0,950$ dan sesudah pelatihan nilai rata-rata meningkat menjadi 4,70 $\pm 0,466$ Hasil analisis bivariat dengan menggunakan uji Wilcoxon, diperoleh nilai Z sebesar 4,684 dan nilai significancy sebesar 0,0001 ( $\mathrm{p}<0,05$ ). Hasil uji statistik ini dapat disimpulkan bahwa ada pengaruh pelatihan basic life support terhadap keterampilan TIM SAR MDMC Banyumas tentang basic life support. karena telah terjadi peningkatan dari 2,83 menjadi 4,70 point (peningkatan sebesar 1,47 point).

Hasil penelitian ini juga sejalan dengan penelitian yang dilakukan oleh Sansare \& Jacob (2018) didapati nilai $\mathrm{p}=0,000<0,005$, sehingga terdapat pengaruh pelatihan terhadap keterampilan. Penelitian lain yang dilakukan oleh Nirmalasari \& Winarti (2020) rata-rata keterampilan sebelum mendapatkan pelatihan yaitu 4,57 (SD 1,99) dan rata-rata keterampilan setelah diberikan pelatihan bantuan hidup dasar yaitu 16,22 (SD 1,20) maka disimpulkan terdapat pengaruh pelatihan BHD dengan keterampilan. Pelatihan merupakan konsep belajar yang berfokus kepada keterampilan. Pelatihan membentuk dasar dari pelaksanaan keterampilan seseorang. Pelatihan seharusnya menjadi hal yang berkesinambungan dengan tujuan mengingat serta memperbarui lagi pengetahuan dan keterampilan yang dimiliki. Pengembangan suatu pengetahuan terlihat dari kemampuan seseorang mampu mengaplikasikannya salah satunya dalam bentuk keterampilan. Pengembangan keterampilan harus dimulai dari apa yang dikuasai responden pada keterampilan yang belum dikuasainya.

Berdasarkan hal tersebut peneliti berasumsi untuk meningkatkan keterampilan perlunya melakukan pelatihan terus menerus sehingga terasah skill dan pengetahuan siswa tersebut

\section{Pengaruh Pelatihan Tindakan RJP terhadap Pengetahuan dan Keterampilan}

Berdasarkan uji paired t test didapati nilai $p$ value $0,000(\mathrm{p}<0,05)$ artinya terdapat pengaruh pelatihan tindakan RJP terhadap pengetahuan dan keterampilan sebelum dan sesudah diberikan pelatihan maka ada perbedaan antara pengetahuan dan keterampilan tindakan RJP sebelum dengan sesudah diberikan pelatihan, sehingga dapat disimpulkan 
pula bahwa ada pengaruh pelatihan tindakan RJP terhadap pengetahuan dan keterampilan siswa anggota PMR SMAN 1 Pekanbaru.

Hasil penelitian ini sejalan dengan penelitian yang dilakukan oleh Supriyanto (2017) didapatkan keterampilan pre dan post penyuluhan dengan $\rho$ value (Asymp. Sig. (2-tailed) $<\rho$ alpha yaitu $0.000<0.05$ yang berarti ada pengaruh pelatihan resusitasi jantung paru terhadap keterampilan.

Pelatihan bantuan hidup dasar bertujuan untuk meningkatkan pengetahuan dan keterampilan dalam pemberian bantuan yang tepat. Sebuah penelitian yang dilakukan oleh Sansare \& Jacob (2018) menunjukkan bahwa hasil pre-test menunjukkan 39 (60\%) responden memiliki pengetahuan yang rendah dan $60(100 \%)$ responden memiliki keterampilan yang rendah. Setelah pelatihan didapatkan hasil post-test $42(70 \%)$ responden berpengetahuan cukup dan $56(93,3 \%)$ responden memiliki keterampilan yang baik. Penelitian tersebut menunjukkan bahwa terjadi peningkatan pengetahuan dan keterampilan setelah diberikan pelatihan $(\mathrm{p}<0.05)$.

Adanya pengaruh pelatihan tindakan RJP terhadap pengetahuan dan keterampilan anggota PMR SMAN 1 Pekanbaru dipengaruhi oleh proses belajar. Proses belajar dalam bentuk pelatihan dapat meningkatkan pengetahuan dan keterampilan serta kepercayaan diri untuk melakukan tindakan RJP. Peningkatan pengetahuan dan keterampilan juga dipengaruhi oleh cara peer education dalam menyampaikan materi dengan menggunakan bahasa yang sederhana sehingga dapat dengan mudah dipahami oleh responden (Gunawan et al., 2018). Sejalan dengan penelitian yang dilakukan Sudarman et al., (2019) menunjukkan ada pengaruh pelatihan bantuan hidup dasar terhadap pengetahuan siswa kelas XI di SMK Baznas Sulawesi Selatan dengan nilai $\alpha=0,001(<0,05)$.

Peneliti beramsusi bahwa untuk meningkatkan pengetahuan dan keterampilan anggota PMR dalam melakukan tindakan RJP maka dapat dilakukan pelatihan secara rutin atau berkala. Alat dan bahan untuk melakukan praktik RJP seperti pantom dan panduan harus disiapkan agar anggota PMR dapat belajar secara berulang. Intensitas anggota PMR dalam berlatih melakukan praktik RJP dapat mempengaruhi siswa menjadi terampil. Ketersediaan video prosedural tindakan RJP juga penting diadakan sebagai salah satu media untuk meningkatkan pengetahuan dan keterampilan anggota PMR. Peneliti juga berpendapat pelatihan tindakan RJP bertujuan untuk meningkatkan tingkat pengetahuan, tingkat keterampilan dan tingkat motivasi anggota PMR dalam melakukan tindakan RJP.

\section{SIMPULAN}

Terdapat pengaruh pelatihan tindakan RJP terhadap pengetahuan dan keterampilan sebelum dan sesudah diberikan pelatihan. Dengan adanya pelatihan tindakan RJP maka akan dapat meningkatkan pengetahuan dan keterampilan anggota PMR sehingga akan dapat terciptanya bystander yang lebih banyak terutama dikalangan usia muda.Diharapkan pelatihan tindakan RJP tersebut dapat menciptakan bystander yang lebih terampil, cepat tanggap dan berani dalam membantu korban-korban henti jantung yang terjadi diluar rumah sakit.

\section{SARAN}

Bagi pelayanan keperawatan dapat menjadikan pengetahuan dan ketrampilan dalam upaya menngkatkan kualitas petugas dalam meberkan pelayanan yang cepat dan tepat. Bagi pendidikan dapat menambah pengetahuan dan meningkatkan ketrampilan 
duntuk menghasilkan petugas yang terdidik dan terlatih yang dibutukhkan oleh masyarakat. Bagi peneliti dapat dijadikan acuan dalam pengembangan dan penelitian selanjutnya.

\section{DAFTAR PUSTAKA}

Achmad, B. F., \& Partorejo, S. (2020). Effectiveness of First-Aid Training in School among High School Students in Kulon Progo, Indonesia. International Journal of Research in Medical Sciences, 8(3), 974. https://doi.org/10.18203/23206012.ijrms20200765

Amisi, W. G., Nelwan, J. E., \& Kolibu, F. K. (2018). Hubungan antara Hipertensi dengan Kejadian Penyakit Jantung Koroner pada Pasien Yang Berobat di Rumah Sakit Umum Pusat Prof. Dr. R. D. Kandou Manado. Kesmas, 7(4), 1-7. https://ejournal.unsrat.ac.id/index.php/kesmas/article/view/23124

BPS. (2020). Sensus Penduduk Provinsi Riau. https://riau.bps.go.id/

Gunawan, H., Achdiat, P. A., \& Rahardjo, R. M. (2018). Tingkat Pengetahuan Penyakit Kusta dan Komplikasinya pada Siswa Sekolah Menengah Atas Negeri Jatinangor. Dharmakarya: Jurnal Aplikasi Iptek untuk Masyarakat, 7(2), 101-105. https://doi.org/10.24198/dharmakarya.v7i2.19379

Herlina, S. (2019). Pengaruh Simulasi Pelatihan Bantuan Hidup Dasar (BHD) terhadap Motivasi dan Skill Resusitasi Jantung Paru (RJP) pada Karang Taruna Rw 06 Depok. Jurnal Keperawatan Widya Gantari Indonesia, 3(2), 7. https://doi.org/10.52020/jkwgi.v3i2.1038

HIPGABI. (2017). Pelatihan Bantuan Hidup Dasar. https://id.scribd.com/document/495462041/Program-Kerja-Hipkabi-2017-2021

Nirmalasari, V., \& Winarti, W. (2020). Pengaruh Pelatihan (BHD) terhadap Pengetahuan dan Keterampilan Mahasiswa Kesehatan Masyarakat. Jurnal $\begin{array}{lllll}\text { Keperawatan Widya Gantari Indonesia, } & \text { 4(2), }\end{array}$ https://doi.org/10.52020/jkwgi.v4i2.1909

Prasetyo, R. D. (2018). Pengaruh Pelatihan Basic Life Support terhadap Pengetahuan dan Keterampilan Tim Sar MDMC Banyumas. Universitas Muhammadiyah Purwokerto. http://repository.ump.ac.id/7946/

Priosusilo, A. P. (2019). Pengaruh Pemberian Pelatihan Bantuan Hidup Dasar terhadap Peningkatan Pengetahuan dan Keterampilan pada Siswa SMKN 1 Geger Madiun. Journal of Chemical Information and Modeling, 53(9), 1689-1699. http://repository.stikes-bhm.ac.id/629/

Sansare, K. R., \& Jacob, S. (2018). Effect Of Basic Life Support Training Programme on Knowledge and Practice Among Administrative Employees of Health Institutes, Navi Mumbai. International Journal of Nursing Education and Research, 6(2), 164. https://doi.org/10.5958/2454-2660.2018.00039.x

Sudarman, S., Asfar, A., \& Pag0, I. (2019). Pengaruh Pelatihan Bantuan Hidup Dasar terhadap Pengetahuan Siswa Kelas XII di SMK Baznas Sulsel. Celebeses Health Journal, 1(1), 49-58. https://journal.lldikti9.id/CPHJ/article/view/ch2519

Supriyanto, M. A. (2017). Pengaruh Pelatihan Resusitasi Jantung Paru terhadap Pengetahuan dan Keterampilan Menolong Korban Henti Jantung pada Orang Awam di Pesantren Miftahul Hasan Desa Gunung Sepikul Pakusari Jember. Universitas Muhammadiyah Jember. http://repository.unmuhjember.ac.id/1040/ 